\title{
Antibiotic Susceptibility Patterns, Biofilm Formation and $e s p$ Gene among Clinical Enterococci: Is There Any Association?
}

\author{
Poh Leng Weng ${ }^{1}\left(\mathbb{D}\right.$, Ramliza Ramli $^{2}$ and Rukman Awang Hamat ${ }^{1, *(\mathbb{D}}$ \\ 1 Department of Medical Microbiology and Parasitology, Faculty of Medicine and Health Sciences, Universiti \\ Putra Malaysia, Serdang, Selangor 43400,Malaysia; fievel_w@yahoo.com \\ 2 Department of Medical Microbiology and Immunology, Universiti Kebangsaan Malaysia Medical Centre, \\ Jalan Yaakob Latif, Bandar Tun Razak, Kuala Lumpur 56000, Malaysia; ramliza@ppukm.ukm.edu.my \\ * Correspondence: rukman@upm.edu.my; Tel.: +60-3-9769-2365; Fax: +60-3-8941-3802
}

Received: 11 July 2019; Accepted: 20 August 2019; Published: 17 September 2019

\begin{abstract}
Enterococci are commonly found in humans, animals and environments. Their highly adaptive mechanisms are related to several virulent determinants and their ability to resist antibiotics. Data on the relationship between the esp gene, biofilm formation and antibiotic susceptibility profiles may differ between countries. This cross-sectional study was conducted to determine the proportion of esp gene and biofilm formation among Enterococcus faecalis and Enterococcus faecium clinical isolates. We also investigated the possible association between the esp gene with antibiotic susceptibility patterns and biofilm formation. The isolates were collected from clinical samples and identified using biochemical tests and 16SRNA. Antibiotic susceptibility patterns and a biofilm assay were conducted according to the established guidelines. Molecular detection by PCR was used to identify the esp gene using established primers. In total, 52 and 28 of E. faecalis and E. faecium were identified, respectively. E. faecium exhibited higher resistance rates compared to E. faecalis as follows: piperacillin/tazobactam (100\% versus $1.9 \%$ ), ampicillin (92.8\% versus $1.9 \%)$, high-level gentamicin resistance (HLGR) $89.3 \%$ versus $25.0 \%$ ) and penicillin $(82.1 \%$ versus $7.7 \%)$. E. faecium produced more biofilms than $E$. faecalis $(59.3 \%$ versus $49.0 \%)$. E. faecium acquired the esp gene more frequently than E. faecalis $(78.6 \%$ versus $46.2 \%$ ). Interestingly, the associations between ampicillin and tazobactam/piperacillin resistance with the esp gene were statistically significant $\left(X^{2}=4.581, p=0.027\right.$; and $X^{2}=6.276, p=0.012$, respectively). Our results demonstrate that $E$. faecium exhibits high rates of antimicrobial resistance, esp gene acquisition and biofilm formation. These peculiar traits of E. faecium may have implications for the management of enterococcal infections in hospitals. Thus, concerted efforts by all parties in establishing appropriate treatment and effective control measures are warranted in future.
\end{abstract}

Keywords: $\operatorname{esp}$ gene; biofilm; antibiotic resistance; enterococci

\section{Introduction}

Human enterococci are normal commensals that reside in the gastrointestinal system as part of our gut microbiota. Surprisingly, they have gained greater interest among scientists owing to their ability to emerge as one of the most important nosocomial opportunistic pathogens worldwide. These highly versatile bacteria are responsible for causing persistently high mortality and morbidity rates in patients with bacteremia, surgical site infections and urinary tract infections [1,2]. Notably, the crude mortality rates of $13 \%$ to $68 \%$ have been reported for enterococcal bacteremia in several retrospective studies $[3,4]$. Among the predominant enterococci observed in humans, Enterococcus faecalis and Enterococcus faecium are the most significant pathogens causing hospital-acquired infections [5]. An initial wave of 
enterococcal infections was dominated by E. faecalis, which contributed to $90 \%$ of the overall cases, while the remaining $10 \%$ were due to E. faecium [6,7]. However, this was replaced by E. faecium as a result of its remarkable resistance to several antibiotics which include vancomycin, ampicillin and high-level aminoglycoside-resistance (HLAR) [8]. Enterococci are well known to demonstrate a high degree of adaptability towards harsh environments, as they can endure extreme temperatures (from $10{ }^{\circ} \mathrm{C}$ to $>45^{\circ} \mathrm{C}$ ), as well as high salt content and $\mathrm{pH}$ levels [6].

In hospital settings, enterococcal survival derives from their ability to rapidly adapt to antimicrobial exposures [9]. Their ability to exhibit rapid genetic mutations has created substantial threats to the swift development of multi-drug resistance strains globally. Vancomycin-resistant enterococci (VRE), for instance, are now being identified as the fourth and fifth leading pathogens causing sepsis in North America and Europe, respectively [10]. This is mainly due to their rapid acquisition of mobile genetic elements (MGEs) such as plasmids, conjugative transposons, integrons and pathogenicity islands (PAIs) [11]. Several antibiotic and virulent determinants have been found in these mobilomes which are readily transmissible [12].

In addition, biofilm formation is one of the strategies for the enterococci to evade the host's immune response and the inhibitory or killing effects of antibiotics [13,14]. This self-produced extracellular matrix also provides a suitable microenvironment for enterococci to grow and facilitates the transmission of mobile genetic elements (MGEs) between bacteria [15]. Enterococcal biofilms have been implicated in indwelling device-related infections such as prosthetic valve endocarditis, prosthetic joint infections and catheter-related infections [16]. Several virulence determinants such as enterococcal surface protein ( $e s p)$ gene, gelatinase ( $g e l E)$ gene and others have been shown to be involved in the propensity of enterococci to form biofilms [14,17]. Nonetheless, many reports have supported the contribution of virulence genes in the formation of enterococcal biofilms, whereas some researchers have reported conflicting findings $[13,17,18]$. Furthermore, the association of the esp gene with biofilm formation displays considerable variations between E. faecalis and E. faecium [17,19,20]. With the conflicting reports on the traits of these highly adaptive bacteria, there remains a question of to what extent biofilm production, virulence and resistance among enterococci are associated. We believe the findings could offer an insight into supporting the proper management of enterococcal infections in hospitals.

Thus, this prompted us to determine the prevalence of the esp gene and to screen for biofilm producers among E. faecalis and E. faecium clinical isolates. Our study was also intended to determine the association of the esp gene with antibiotic susceptibility patterns and biofilm formation. To the best of our knowledge, existing data on the association between these variables in Malaysian enterococcal isolates is still lacking. We have previously established the wide distribution of virulent genes among our clinical enterococci, excepting the esp determinant and biofilm formation [21].

\section{Materials and Methods}

\subsection{Clinical Enterococci Isolation}

Clinical enterococci were isolated from a tertiary hospital during a one-year study period (from 1 December 2014 to 1 December 2015) using a cross-sectional study approach. A total of 52 and $28 E$. faecalis and E. faecium isolates, respectively, were obtained from various samples such as pus $(n=41)$, blood $(n=27)$, urine $(n=8)$, high vaginal swabs $(n=2)$ and others $(n=2)$. All isolates were cultured in several media accordingly (selective and non-selective) based on established protocols. The identity of the isolates was confirmed by using several procedures such as conventional biochemical tests [22], Remel RapID Strep Kit (Oxford, UK), and species-specific PCR which has previously been described by Kariyama et al. [23]. 


\subsection{Antibiotic Susceptibility Testing}

The Kirby-Bauer disk diffusion method was used for antibiotic susceptibility testing. The following antibiotic discs were used: penicillin (10 Unit, Oxoid), ampicillin (10 $\mu \mathrm{g}$, Oxoid) high-level gentamicin resistance (HLGR) $(120 \mu \mathrm{g}$, Oxoid), piperacillin/tazobactam (100/10 $\mu \mathrm{g}$, Oxoid), teicoplanin (30 $\mu \mathrm{g}$, Oxoid) and vancomycin ( $30 \mu \mathrm{g}$, Oxoid). All results were interpreted according to the Clinical and Laboratory Standards Institute guidelines [24].

\subsection{Screening of Enterococcal Biofilms}

The biofilm formation was screened by using the colorimetric assay according to the established protocol with slight modifications [13]. Briefly, a total of $200 \mu \mathrm{L}$ bacterial solution containing trypticase soy broth (TSB) (Oxoid, UK) supplemented with $0.25 \%$ glucose was added into a sterile 96-well microtiter plate. The microtiter plate was incubated at $37^{\circ} \mathrm{C}$ for $24 \mathrm{~h}$. Then, the medium was gently removed and the wells were washed three times with $100 \mu \mathrm{L}$ of Phosphate Buffer Saline (PBS) before being allowed to dry for $1 \mathrm{~h}$. The wells were stained with $100 \mu \mathrm{L}$ of $0.2 \%$ crystal violet (Merck, Germany) for $15 \mathrm{~min}$ at room temperature. The unbound crystal violet was removed by washing the wells three times with PBS and the crystal violet was solubilized by adding $200 \mu \mathrm{L}$ of $33 \%$ acetic acid. Finally, the plate was read at $595 \mathrm{~nm}$ using a microtiter plate reader (Dynex Technologies, Chantilly, VA, USA). The procedure was performed in triplicate for each sample. The strains were classified as no biofilm producer, weak biofilm producer, moderate biofilm producer and strong biofilm producer, according to the established protocol by Stepanovic et al. [25].

\subsection{Molecular Detection of the Enterococcal Surface Protein (esp) Gene}

DNA extraction was performed by using a Masterpure Complete DNA purification kit (Epicentre Technologies, Wisconsin, WI, USA) according to the manufacturer's instructions. The esp gene was detected using PCR with established forward and reverse primers as follows: esp F, 5'-TTG CTA ATG CTA GTC CAC GAC C-3'; esp R, 5'-GCG TCA ACA CTT GCA TTG CCG AA-3' (Ramadhan and Hegedus). The reaction mixtures were prepared which consisted of the following: $25 \mu \mathrm{L}$ PCR master mixture of $12.5 \mu \mathrm{L}$ Gotaq green master mix (Promega, USA), $0.5 \mu \mathrm{L}$ primer $(10 \mathrm{mM}), 9.5 \mu \mathrm{L}$ sterile ultrapure water (Milipore, Burlington, MA, USA), and $2 \mu \mathrm{L}$ DNA. The PCR conditions were carried out as follows: an initial denaturation step at $95^{\circ} \mathrm{C}$ for $15 \mathrm{~min} ; 30$ cycles of denaturation at $90^{\circ} \mathrm{C}$ for $30 \mathrm{~s}$, annealing at $58{ }^{\circ} \mathrm{C}$ for $1 \mathrm{~min}$, and an extension at $72{ }^{\circ} \mathrm{C}$ for $1 \mathrm{~min}$; a final extension at $72{ }^{\circ} \mathrm{C}$ for $10 \mathrm{~min}$. The PCR products were viewed under the UV imager (Alpha Imager ${ }^{\mathrm{TM}}$ 2200, Alpha Innotech Corporation, California, CA, USA) using $0.8 \%$ agarose gel at $70 \mathrm{~V}$ with Lambda HindIII marker.

\subsection{Statistical Analysis}

Chi-square analysis was employed to test the relationship between certain variables, such as the esp gene versus antibiotic susceptibility patterns and biofilm formation. The $p$ value of $<0.05$ was considered as statistically significant. The analysis was conducted using (SPSS Inc., v. 19, Chicago, IL, USA).

\section{Results}

\subsection{Antibiotic Susceptibility Patterns}

Of 80 clinical specimens, $63.8 \%$ and $36.2 \%$ were from invasive and non-invasive isolation sites, respectively. E. faecalis isolates exhibited high susceptibility rates towards ampicillin $(98.1 \%)$, piperacillin/tazobactam (98.1\%), penicillin (92.3\%), and high-level gentamicin resistance (HLGR) $(75.0 \%)$. On the other hand, E. faecium isolates demonstrated high resistance rates towards piperacillin/tazobactam (100\%), ampicillin (92.8\%), HLGR (89.3\%) and penicillin (82.1\%). However, no resistance to teicoplanin or vancomycin was detected in either species (Table 1). 
Table 1. Rates of antibiotic resistance in clinical enterococci.

\begin{tabular}{ccc}
\hline Antibiotic & Enterococcus faecalis $\boldsymbol{n} \%$ & Enterococcus faecium $\boldsymbol{n} \%$ \\
\hline Penicillin & $4(7.7)$ & $23(82.1)$ \\
\hline Ampicillin & $1(1.9)$ & $26(92.8)$ \\
\hline Tazobactam/piperacillin & $1(1.9)$ & $28(100)$ \\
\hline High-level gentamicin resistance (HLGR) & $13(25.0)$ & $25(89.3)$ \\
\hline Vancomycin & $0(0)$ & $0(0)$ \\
\hline Teicoplanin & $0(0)$ & $0(0)$ \\
\hline
\end{tabular}

\subsection{Biofilm Colometric Assay}

In total, 41 (52.6\%) clinical enterococci produced biofilms whereas 37 (47.4\%) did not. Among biofilm producers, E. faecium isolates exhibited higher biofilm formation than E. faecalis (59.3\% versus $49.0 \%$ ). However, strong biofilm producers were demonstrated by both species in almost equal percentages (28.0\% and $25.0 \%$ of E. faecalis and E. faecium, respectively). The distribution of biofilm formation according to the classification of biofilm formation among E. faecalis and E. faecium isolates is shown in Figure S1 in Supplementary Materials. Only 78 clinical enterococci were recruited as two isolates were lost during the procedure (one each for E. faecalis and E. faecium).

\subsection{Detection of the esp Gene}

In our study, the overall prevalence of the esp gene among clinical enterococci isolates was $57.5 \%$. According to the type of enterococcal species, $78.6 \%$ and $46.2 \%$ of E. faecium and E. faecalis carried the esp gene, respectively. PCR products were visualized for the presence of the esp gene (Figure S2 in Supplementary Materials).

\subsection{Associaton between the esp Gene with Antimicrobial Resistance and Biofilms}

The association between each antibiotic resistance and the presence of the esp gene is shown in Table 2. The esp gene was present in ampicillin-resistant isolates more frequently than in ampicillin-sensitive isolates ( $25.0 \%$ versus $8.7 \%$ ). Similarly, tazobactam/piperacillin-resistant isolates exhibited a higher frequency of esp gene compared to tazobactam/piperacillin-sensitive isolates ( $25.0 \%$ versus $10.0 \%)$. The associations between ampicillin and tazobactam/piperacillin resistance with the esp gene were statistically significant $\left(X^{2}=4.581 ; p=0.032\right.$ and $X^{2}=6.276 ; p=0.012$, respectively). There were no significant associations found between penicillin resistance and HLGR with the esp gene $\left(X^{2}=0.498 ; p=0.481\right.$ and $X^{2}=2.035 ; p=0.154$, respectively). In addition, there was no significant association between the presence of the esp gene and biofilm formation $\left(X^{2}=0.007 ; p=0.934\right)$. Table 3 shows the association between the esp gene and biofilm formation among our clinical enterococci isolates.

Table 2. The association between antibiotic susceptibility patterns and the esp gene among clinical enterococci.

\begin{tabular}{|c|c|c|c|}
\hline \multirow{2}{*}{$\begin{array}{c}\text { Antibiotic } \\
\text { Susceptibility Patterns }\end{array}$} & \multicolumn{2}{|c|}{ Enterococcal Surface Protein (esp) Gene $n(\%)$} & \multirow{2}{*}{$p$ Value } \\
\hline & Positive & Negative & \\
\hline $\mathrm{PEN}^{\mathrm{S}}$ & $29(30.5)$ & $24(22.5)$ & \multirow{2}{*}{0.481} \\
\hline $\mathrm{PEN}^{\mathrm{R}}$ & $17(15.5)$ & $10(11.5)$ & \\
\hline $\mathrm{AMP}^{\mathrm{S}}$ & $26(30.5)$ & $27(22.5)$ & \multirow{2}{*}{$0.032 *$} \\
\hline $\mathrm{AMP}^{\mathrm{R}}$ & $20(15.5)$ & $7(11.5)$ & \\
\hline HLGR $^{S}$ & $21(24.2)$ & $21(17.9)$ & \multirow{2}{*}{0.154} \\
\hline HLGR $^{\mathrm{R}}$ & $25(21.9)$ & $13(16.2)$ & \\
\hline $\mathrm{TZP}{ }^{\mathrm{S}}$ & $24(29.3)$ & $27(21.7)$ & \multirow{2}{*}{0.012 * } \\
\hline $\mathrm{TZP} \mathrm{P}^{\mathrm{R}}$ & $22(16.7)$ & $7(12.3)$ & \\
\hline
\end{tabular}

PEN: penicillin, AMP: ampicillin, TZP: tazobactam/piperacillin, HLGR: high-level gentamicin resistance (gentamicin 120), S: sensitive, R: resistant. Vancomycin and teicoplanin were excluded for the analysis for all enterococci were sensitive to both antibiotics. ${ }^{*} p$-value $<0.05$ was considered significant. 
Table 3. The association between the esp gene and biofilm formation among clinical enterococci.

\begin{tabular}{|c|c|c|c|}
\hline \multirow{2}{*}{ esp Gene } & \multicolumn{2}{|c|}{ Biofilm Formation $n^{\dagger}(\%)$} & \multirow{2}{*}{$p$ Value * } \\
\hline & Yes & No & \\
\hline Positive & $24(52.2)$ & $22(47.8)$ & \multirow{2}{*}{0.934} \\
\hline Negative & $17(53.1)$ & $15(46.9)$ & \\
\hline
\end{tabular}

\section{Discussion}

In general, E. faecium exhibited higher resistance rates toward selected antibiotics than E. faecalis in our study. Ampicillin and HLGR are of concern. Ampicillin-resistant E. faecium isolates have now become widespread worldwide [26,27]. The reduced affinity of penicillin-binding proteins and plasmid-mediated $\beta$-lactamases is responsible for these resistance traits [28]. It is believed that the dissemination of the chromosomally encoded penicillin-binding protein 5 (PBP5) gene by enterococcal conjugative plasmids among clinical enterococci isolates might contribute to a global spread [29]. Nonetheless, the synergistic combination of penicillin/ampicillin ( $\beta$-lactams drugs) and aminoglycoside can be useful in treating serious enterococcal infections [30]. In our study, E. faecium exhibited higher rates of HGLR than E. faecalis isolates (89.3\% versus $25.0 \%$ ), thus this synergism could not be the best therapeutic option in managing infections caused by E. faecium in our clinical setting. Our findings are consistent with data from other countries as well [31,32].

One of the novel strategies the enterococci use in order to be consistently present in hospital environments is the formation of biofilms which could allow them to adhere to any surfaces [33]. It has been proposed that biofilms are pivotal in the pathogenesis of enterococcal infections, especially in urinary tract infections [34]. In the present study, a higher production of biofilms was observed among E. faecium than E. faecalis isolates (59.3\% versus $49.0 \%$ ). Our finding is in accordance with other studies in which E. faecium clinical strains produced more biofilms than others [35]. Higher rates of biofilm formation in E. faecium were also observed in Poland and Spain (77.8 and 75\%, respectively) $[15,36]$. However, several studies have found a reduced formation of biofilms among E. faecium compared to $E$. faecalis isolates $[12,18,27]$. For instance, biofilm formation was more highly reported in $E$. faecalis than E. faecium isolates in Italy ( $80 \%$ versus $48 \%$ ) [37]. In the UK, among 109 enterococci, $100 \%$ and $42 \%$ of E. faecalis and E. faecium isolates produced biofilms, respectively [38]. Surprisingly, none of the $25 E$. faecium produced biofilms compared to $26 \%$ of E. faecalis isolates in a study among 171 enterococci in India [39]. It seems that there are differences in terms of the prevalence rates of biofilm formation among these two important clinical enterococci. Nonetheless, the true prevalence of biofilm formation among clinical enterococci is still unknown and it may vary according to the type of methodology, nature of specimens, type of strains and geographical location.

In our study, E. faecium carried the esp gene more frequently than E. faecalis (78.6\% versus $46.2 \%)$. The prevalence rate of the esp gene among these two common enterococci species varies from country to country. For instance, a study in Brazil reported that $70 \%$ of 240 enterococci exhibited the esp gene, with E. faecalis and E. faecium accounting for $70.1 \%$ and $68.4 \%$ of those, respectively [27]. However, only 13 E. faecium isolates were enrolled in their study. In another study, $60 \%$ and $41.5 \%$ of clinical enterococci exhibited the esp gene in Puerto Rico and Southern California, respectively [40]. Prevalence rates of only $33.3 \%$ and $30 \%$ of the esp gene were detected in E. faecalis isolates in these two study locations. In contrast, higher detection rates of the esp gene (73\% and $83 \%$ ) were reported among E. faecium isolates in the same locations. A smaller number of E. faecium isolates were also observed in their study. Enterococcal surface protein (Esp) is an important virulence factor that is located on a pathogenicity island [41]. This potential surface protein is expressed on the cell wall of the enterococci and it is known to be predominantly found in nosocomial strains of E. faecium, which is in accordance with our findings [13]. Interestingly, the esp gene was more prevalent in clinical enterococci than environmental enterococci, as reported in a study in Australia [42]. In contrast to our findings, in a local study 
involving 90 E. faecalis and 12 E. faecium isolates from three different hospitals in Northeastern Malaysia, E. faecalis exhibited the esp gene more frequently than E. faecium ( $49.2 \%$ versus $30.8 \%$, respectively) [43]. It seems that different hospital settings may produce different distributions of the esp gene among enterococci, even from the same geographic location. The possession of the esp gene in E. faecalis and E. faecium isolates has been implicated in chronic infections of the urinary system in animal models. It has been observed that Esp could increase the pathogenicity of E. faecium by adhering to the uroepithelial cells [44]. Similar observations have been reported in E. faecalis isolates as well [45]. Recent data have also shown that the induction of the expression of pro-inflammatory cytokines was initiated by esp via the activation of the NF-kB pathway in vitro [46]. However, the exact mechanism of the activation is still unknown.

Moreover, the genetic lineage of E. faecium is distinct from enterococcal gut flora [41]. Thus, it seems that nosocomial E. faecium strains have developed a special trait for their versatile adaptation to well-established hospital environments. This is further supported by the recognition of clade A or hospital-associated clade of nosocomial E. faecium isolates through the whole genome sequencing-based studies [47]. These strains are equipped with many virulence genes including esp and others. Surprisingly, the presence of the esp gene in E. faecium isolates has been shown to signify potential outbreaks in hospitals $[37,41]$. Regarding E. faecalis, there is no distinct genetic trait that has been reported among this species in the literature until now. This could be explained by the possibility of extensive gene recombination, which may have occurred since E. faecalis is ubiquitously found in almost all animals and insects which in turn could lead to the absence of predominant clones [47].

Since the esp gene is an important marker for pathogenicity island (PAI) and biofilm formation in clinical enterococci, it is worth examining the possible association between the presence of the esp gene and antimicrobial resistance. In our study, esp-positive enterococci were strongly associated with resistance to ampicillin $(p=0.032)$ and piperacillin/tazobactam $(p=0.012)$. Since the majority of the resistance was due to E. faecium, it can be concluded that the esp-positive E. faecium isolates were resistant to these antibiotics. Interestingly, hospital-adapted strains of E. faecium were strongly associated with ampicillin resistance and the acquisition of PAI, such as the esp gene and clonal-complex 17 (CC-17) [41]. More interestingly, esp-positive E. faecium isolates demonstrated higher resistance rates to $\beta$-lactams drugs in Sweden, which is consistent with our study [48]. It has been postulated that the absence of Esp-a large cell wall protein —-would lead to subtle changes to the cell wall of enterococci, that could indirectly modify the susceptibility pattern toward ampicillin [49].

Enterococcal biofilm formation is a very complex process and the involvement of potential virulent factors in this process is highly contentious [35]. The esp gene has been shown to be important in biofilm formation [20]. The interaction between the esp gene and biofilms would establish the success rates of enterococcal infections, especially for those strains that are isolated from blood and urine samples $[17,18]$. In our study, there was no significant association between the esp gene (in both species) and biofilm formation $(p=0.934)$. Similar observations were also reported in several studies $[50,51]$. It has been concluded that the Esp protein is not crucial for the formation of biofilms and other biofilm-associated proteins-such as gelatinase (encoded by gelE) and aggregation substance (encoded by agg)—-may be involved [13,49]. Nonetheless, a significant association between the esp gene and biofilm formation was observed among 240 clinical enterococci in a study in Brazil $(p<0.0001)$ [27].

Our study has several limitations. Firstly, the current study has only involved clinical samples from a hospital, thus, the findings cannot be generalized to all Malaysian hospitals. A multicenter study could produce more reliable information in future. Secondly, other samples from animals and the environment should be included to study the genetic evolution of enterococci, because any significant findings may be useful to relevant authorities in managing enterococcal diseases by a One Health Concept accordingly. Thirdly, it would be interesting to investigate the loci of $\beta$-lactams resistance and esp genes via molecular approaches. We could thereby ascertain whether the genes are carried by the same or different mobile genetic elements. Lastly, few other biofilm-related genes that are involved in enterococcal biofilm formation should be included as biofilm formation is a very complex process 
and multiple virulent genes may be involved. Nonetheless, our findings could offer an insight into the current status of clinical enterococci which is biologically and geographically different from other strains reported in many countries, and to our knowledge, this is the only study investigating the association between the esp gene with the susceptibility patterns of selected antibiotics and biofilm formation that has been reported so far in Malaysia.

\section{Conclusions}

In conclusion, our E. faecium isolates display higher resistance rates toward selected antibiotics (in particular of ampicillin and tazobactam/piperacillin) compared to E. faecalis, which could change the therapeutic options for patients infected with this strain. The presence of the esp gene among antibiotic-resistant $E$. faecium isolates would ensure their successful establishment in hospital settings, which may have implications for the management of enterococcal infections in hospitals. Hence, the close monitoring of ampicillin and tazobactam/piperacillin-resistant E. faecium isolates is crucial for the development of effective control measures in future.

Supplementary Materials: The following are available online at http://www.mdpi.com/1660-4601/16/18/3439/s1, Figure S1: The classification of biofilm formation among E. faecalis and E. faecium isolates; Figure S2: Gel electrophoresis image of esp gene.

Author Contributions: Conceptualization: P.L.W., and R.A.H.; methodology: P.L.W., and R.A.H.; validation: R.R., and R.A.H.; formal analysis: P.L.W.; investigation: P.L.W., R.R., and R.A.H.; data curation: R.R., and R.A.H.; writing—original draft preparation: P.L.W.; writing—review and editing: R.A.H.; supervision: R.R., and R.A.H.; project administration: R.A.H.

Funding: We acknowledge the support of the Faculty of Medicine and Health Sciences, Universiti Putra Malaysia and Open Access Publishing Fund of Research Management Center, Universiti Putra Malaysia.

Acknowledgments: The authors wish to extend their very special thanks to Universiti Kebangsaan Malaysia Medical Centre and their staff for providing the clinical samples. We would like to thank Associate Professor Dr Malina Osman for her input on statistical data and analysis. We are grateful for the constructive comments of the anonymous reviewers.

Conflicts of Interest: The authors declare no conflict of interest. The funders had no role in the design of the study; in the collection, analyses, or interpretation of data; in the writing of the manuscript, or in the decision to publish the results.

\section{References}

1. Richards, M.J.; Edwards, J.R.; Culver, D.H.; Gaynes, R.P. Nosocomial infections in combined medical-surgical intensive care units in the United States. Infect. Control. Hosp. Epidemiol. 2000, 21, 510-515. [CrossRef] [PubMed]

2. Billington, E.O.; Phang, S.H.; Gregson, D.B.; Pitout, J.D.; Ross, T.; Church, D.L.; Laupl, K.B.; Parkins, M.D. Incidence, risk factors, and outcomes for Enterococcus spp. blood stream infections: A population-based study. Int. J. Infect. Dis. 2014, 26, 76-82. [CrossRef] [PubMed]

3. Caballero-Granado, F.J.; Becerril, B.; Cuberos, L.; Bernabeu, M.; Cisneros, J.M.; Pachón, J. Attributable mortality rate and duration of hospital stay associated with enterococcal bacteremia. Clin. Infect. Dis. 2001, 32, 587-594. [CrossRef] [PubMed]

4. Poh, C.H.; Oh, H.M.; Tan, A.L. Epidemiology and clinical outcome of enterococcal bacteremia in an acute care hospital. J. Infect. 2006, 52, 383-386. [CrossRef] [PubMed]

5. Korten, V.; Murray, B.E. The nosocomial transmission of enterococci. Curr. Opin. Infect. Dis. 1993, 6, $498-505$. [CrossRef]

6. Murray, B.E. The life and times of the Enterococcus. Clin. Microbiol. Rev. 1990, 3, 46-65. [CrossRef] [PubMed]

7. Jones, M.E.; Draghi, D.C.; Thornsberry, C.; Karlowsky, J.A.; Sahm, D.F.; Wenzel, R.P. Emerging resistance among bacterial pathogens in the intensive care unit-A European and North American surveillance study (2000-2002). Ann. Clin. Microbiol. Antimicrob. 2004, 3, 14. [CrossRef] [PubMed]

8. Willems, R.J.L.; van Schaik, W. Transition of Enterococcus faecium from commensal organism to nosocomial pathogen. Future Microbiol. 2009, 4, 1125-1135. [CrossRef] 
9. Donskey, C.J.; Chowdhry, T.K.; Hecker, M.T.; Hoyen, C.K.; Hanrahan, J.A.; Hujer, A.M.; Hutton-Thomas, R.A.; Whalen, C.C.; Bonomo, R.A.; Rice, L.B. Effect of antibiotic therapy on the density of vancomycin-resistant enterococci in the stool of colonized patients. N. Engl. J. Med. 2000, 343, 1925-1932. [CrossRef]

10. Deshpande, L.M.; Fritsche, T.R.; Moet, G.J.; Biedenbach, D.J.; Jones, R.N. Antimicrobial resistance and molecular epidemiology of vancomycin-resistant enterococci from North America and Europe: A report from the SENTRY Antimicrobial Surveillance Program. Diagn. Microbiol. Infect. Dis. 2007, 58, 163-170. [CrossRef]

11. Hegstad, K.; Mikalsen, T.; Coque, T.M.; Werner, G.; Sundsfjord, A. Mobile genetic elements and their contribution to the emergence of antimicrobial resistant Enterococcus faecalis and Enterococcus faecium. Clin. Microbiol. Infect. 2010, 16, 541-554. [CrossRef] [PubMed]

12. Willems, R.J.; Top, J.; van Schaik, W.; Leavis, H.; Bonten, M.; Sirén, J.; Hanage, W.P.; Corander, J. Restricted gene flow among hospital subpopulations of Enterococcus faecium. MBio 2012, 3, e00151-12. [CrossRef] [PubMed]

13. Heikens, E.; Bonten, M.J.; Willems, R.J. Enterococcal surface protein Esp is important for biofilm formation of Enterococcus faecium E1162. J. Bacteriol. 2007, 189, 8233-8240. [CrossRef] [PubMed]

14. Paganelli, F.L.; Willems, R.J.; Jansen, P.; Hendrickx, A.; Zhang, X.; Bonten, M.J.; Leavis, H.L. Enterococcus faecium biofilm formation: Identification of major autolysin AtlAEfm, associated Acm surface localization, and AtlAEfm-independent extracellular DNA release. MBio 2013, 4, e00154. [CrossRef] [PubMed]

15. Sieńko, A.; Wieczorek, P.; Majewski, P.; Ojdana, D.; Wieczorek, A.; Olszańska, D.; Tryniszewska, E. Comparison of antibiotic resistance and virulence between biofilm-producing and non-producing clinical isolates of Enterococcus faecium. Acta. Biochim. Pol. 2015, 62, 859-866. [CrossRef] [PubMed]

16. Donlan, R.M. Biofilms: Microbial life on surfaces. Emerg. Infect. Dis. 2002, 8, 881-890. [CrossRef] [PubMed]

17. Di Rosa, R.; Creti, R.; Venditti, M.; D'Amelio, R.; Arciola, C.R.; Montanaro, L.; Baldassarri, L. Relationship between biofilm formation, the enterococcal surface protein (Esp) and gelatinase in clinical isolates of Enterococcus faecalis and Enterococcus faecium. FEMS Microbiol. Lett. 2006, 256, 145-150. [CrossRef] [PubMed]

18. Mohamed, J.A.; Huang, D.B. Biofilm formation by enterococci. J. Med. Microbiol. 2007, 56, 1581-1588. [CrossRef] [PubMed]

19. Toledo-Arana, A.; Valle, J.; Solano, C.; Arrizubieta, M.J.; Cucarella, C.; Lamata, M.; Amorena, B.; Leiva, J.; Penades, J.R.; Lasa, I. The enterococcal surface protein, Esp, is involved in Enterococcus faecalis biofilm formation. Appl. Environ. Microbiol. 2001, 67, 4538-4545. [CrossRef]

20. Van Wamel, W.J.; Hendrickx, A.P.; Bonten, M.J.; Top, J.; Posthuma, G.; Willems, R.J. Growth condition-dependent Esp expression by Enterococcus faecium affects initial adherence and biofilm formation. Infect. Immun. 2007, 75, 924-931. [CrossRef]

21. Soheili, S.; Ghafourian, S.; Sekawi, Z.; Neela, V.; Sadeghifard, N.; Ramli, R.; Hamat, R.A. Wide distribution of virulence genes among Enterococcus faecium and Enterococcus faecalis clinical isolates. Sci. World J. 2014. [CrossRef] [PubMed]

22. Mahon, C.R.; Lehman, D.C.; Manuselis, G. Textbook of Diagnostic Microbiology, 4th ed.; Saunders: Philadelphia, PA, USA, 2007.

23. Kariyama, R.; Mitsuhata, R.; Chow, J.W.; Clewell, D.B.; Kumon, H. Simple and reliable multiplex PCR assay for surveillance isolates of vancomycin-resistant enterococci. J. Clin. Microbiol. 2000, 38, 3092-3095. [PubMed]

24. Clinical and Laboratory Standards Institute (CLSI). Performance Standards for Antimicrobial Susceptibility Testing; Twenty-Fourth Informational Supplement, M100-S24; CLSI Press: Wayne, PA, USA, 2014; pp. 44-128.

25. Stepanovic, S.; Vuković, D.; Hola, V.; DI Bonaventura, G.; Djukić, S.; Cirković, I.; Ruzicka, F. Quantification of biofilm in microtiter plates: Overview of testing conditions and practical recommendations for assessment of biofilm production by staphylococci. APMIS 2007, 115, 891-899. [CrossRef] [PubMed]

26. Jureen, R.; Top, J.; Mohn, S.C.; Harthug, S.; Langeland, N.; Willems, R.J.L. Molecular characterization of ampicillin-resistant Enterococcus faecium isolates from hospitalized patients in Norway. J. Clin. Microbiol. 2003, 41, 2330-2336. [CrossRef] [PubMed]

27. Soares, R.O.; Fedi, A.C.; Reiter, K.C.; Caierao, J.; d'Azevedo, P.A. Correlation between biofilm formation and gelE, esp, and agg genes in Enterococcus spp. clinical isolates. Virulence 2014, 5, 634-637. [CrossRef] [PubMed]

28. Cetinkaya, Y.; Falk, P.; Mayhall, C.G. Vancomycin-resistant enterococci. Clin. Microbiol. Rev. 2000, 13, 686-707. [CrossRef] [PubMed] 
29. Rice, L.B. Beta-lactam antibiotics and gastrointestinal colonization with vancomycin-resistant enterococci. J. Infect. Dis. 2005, 24, 804-814. [CrossRef]

30. Aslangul, E.; Massias, L.; Meulemans, A.; Chau, F.; Andremont, A.; Courvalin, P.; Fantin, B.; Ruimy, R. Acquired gentamicin resistance by permeability impairment in Enterococcus faecalis. Antimicrob. Agents Chemother. 2006, 50, 3615-3621. [CrossRef]

31. Panesso, D.; Reyes, J.; Rincón, S.; Díaz, L.; Galloway-Peña, J.; Zurita, J.; Carrillo, C.; Merentes, A.; Guzmán, M.; Adachi, J.A.; et al. Molecular epidemiology of vancomycin-resistant Enterococcus faecium: A prospective, multicenter study in South American hospitals. J. Clin. Microbiol. 2010, 48, 1562-1569. [CrossRef]

32. Araoka, H.; Kimura, M.; Yoneyama, A. A surveillance of high-level gentamicin-resistant enterococcal bacteremia. J. Infect. Chemother. 2011, 17, 433-434. [CrossRef]

33. Tenke, P.; Köves, B.; Nagy, K.; Hultgren, S.J.; Mendling, W.; Wullt, B.; Grabe, M.; Wagenlehner, F.M.; Cek, M.; Pickard, R.; et al. Update on biofilm infections in the urinary tract. World J. Urol. 2012, 30, 51-57. [CrossRef] [PubMed]

34. Mohamed, J.A.; Huang, W.; Nallapareddy, S.R.; Teng, F.; Murray, B.E. Influence of origin of isolates, especially endocarditis isolates, and various genes on biofilm formation by Enterococcus faecalis. Infect. Immun. 2004, 72, 3658-3663. [CrossRef] [PubMed]

35. Almohamad, S.; Somarajan, S.R.; Singh, K.V.; Nallapareddy, S.R.; Murray, B.E. Influence of isolate origin and presence of various genes on biofilm formation by Enterococcus faecium. FEMS Microbiol. Lett. 2014, 353, 151-156. [CrossRef] [PubMed]

36. Latasa, C.; Solano, C.; Penadés, J.R.; Lasa, I. Biofilm-associated proteins. C. R. Biol. 2016, 329, $849-857$. [CrossRef] [PubMed]

37. Baldassarri, L.; Cecchini, R.; Bertuccini, L.; Ammendolia, M.G.; Iosi, F.; Arciola, C.R.; Montanaro, L.; Di Rosa, R.; Gherardi, G.; Dicuonzo, G.; et al. Enterococcus spp. produces slime and survives in rat peritoneal macrophages. Med. Microbiol. Immunol. 2001, 190, 113-120. [CrossRef] [PubMed]

38. Sandoe, J.A.; Witherden, I.R.; Cove, J.H.; Heritage, J.; Wilcox, M.H. Correlation between enterococcal biofilm formation in vitro and medical-device-related infection potential in vivo. J. Med. Microbiol. 2003, 52, 547-550. [CrossRef] [PubMed]

39. Prakash, V.P. Clinical Prevalence, Identification and Molecular Characterization of Enterococci. Ph.D. Thesis, Pondicherry University, Pondicherry, India, June 2005.

40. Ferguson, D.M.; Talavera, G.N.; Hernandez, L.A.; Weisberg, S.B.; Ambrose, R.F.; Jay, J.A. Virulence genes among Enterococcus faecalis and Enterococcus faecium isolated from coastal beaches and human and nonhuman sources in Southern California and Puerto Rico. J. Pathog. 2016. [CrossRef] [PubMed]

41. Willems, R.J.; Top, J.; van Santen, M.; Robinson, D.A.; Coque, T.M.; Baquero, F.; Grundmann, H.; Bonten, M.J. Global spread of vancomycin resistant Enterococcus faecium from distinct nosocomial genetic complex. Emerg. Infect. Dis. 2005, 11, 821-828. [CrossRef]

42. Rathnayake, I.U.; Hargreaves, M.; Huygens, F. Antibiotic resistance and virulence traits in clinical and environmental Enterococcus faecalis and Enterococcus faecium isolates. Syst. Appl. Microbiol. 2012, 35, 326-333. [CrossRef]

43. Al-Talib, H.; Zuraina, N.; Kamarudin, B.; Yean, C.Y. Genotypic variations of virulent genes in Enterococcus faecium and Enterococcus faecalis isolated from three hospitals in Malaysia. Adv. Clin. Exp. Med. 2015, 24, 121-127. [CrossRef]

44. Leendertse, M.; Heikens, E.; Wijnands, L.M.; van Luit-Asbroek, M.; Teske, G.J.; Roelofs, J.J.; Bonten, M.J.; van der Poll, T.; Willems, R.J. Enterococcal surface protein transiently aggravates Enterococcus faecium-Induced urinary tract infection in mice. J. Infect. Dis. 2009, 200, 1162-1165. [CrossRef] [PubMed]

45. Shankar, N.C.; Lockatell, C.V.; Baghdayan, A.S.; Drachenberg, C.; Gilmore, M.S.; Johnson, D.E. Role of Enterococcus faecalis surface protein Esp in the pathogenesis of ascending urinary tract infection. Infect. Immun. 2001, 69, 4366-4372. [CrossRef]

46. Zou, J.; Shankar, N. Surface protein Esp enhances proinflammatory cytokine expression through NF-kappaB activation during enterococcal infection. Innate. Immun. 2016, 22, 31-39. [CrossRef] [PubMed]

47. Guzman Prieto, A.M.; van Schaik, W.; Rogers, M.R.; Coque, T.M.; Baquero, F.; Corander, J.; Willems, R.J. Global emergence and dissemination of enterococci as nosocomial pathogens: Attack of the clones? Front. Microbiol. 2016, 7, 788. [CrossRef] [PubMed] 
48. Billström, H.; Sullivan, A.; Lund, B. Cross-transmission of clinical Enterococcus faecium in relation to esp and antibiotic resistance. J. Appl. Microbiol. 2008, 105, 2115-2122. [CrossRef] [PubMed]

49. Meredith, K.; Bolhuis, A.; O'Neill, M.A.A. Enterococcal surface protein Esp affects antibiotic sensitivity in Enterococcus faecium. Int. J. Antimicrob. Agents 2009, 34, 392-393. [CrossRef] [PubMed]

50. Kafil, H.S.; Mobarez, A.M.; Moghadam, M.F. Adhesion and virulence factor properties of enterococci isolated from clinical samples in Iran. Indian J. Pathol. Microbiol. 2013, 56, 238-242. [CrossRef] [PubMed]

51. Ramadhan, A.A.; Hegedus, E. Biofilm formation and esp gene carriage in enterococci. J. Clin. Pathol. 2005, 58, 685-686. [CrossRef] [PubMed]

(C) 2019 by the authors. Licensee MDPI, Basel, Switzerland. This article is an open access article distributed under the terms and conditions of the Creative Commons Attribution (CC BY) license (http://creativecommons.org/licenses/by/4.0/). 